\title{
Comparative therapeutic use of Risedronate and Calcarea phosphorica - allopathy versus homeopathy - in bone repair in castrated rats
}

\section{Comparação do uso terapêutico de Risedronato e Calcarea phosphorica - alopatia versus homeopatia - no reparo ósseo em ratos castrados}

\author{
Cristina Werkman* \\ Giselle Segnini Senra* \\ Rosilene Fernandes da Rocha** \\ Adriana Aigotti Haberbeck Brandão***
}

\begin{abstract}
Osteoporosis, a disease characterized by progressive bone loss, has been the target of several studies in the past few years. It results in a much higher risk for fractures and might cause slower bone lesion healing. The aim of this work was to study the effects of Risedronate (allopathic medicine) and Calcarea phosphorica $6 \mathrm{CH}$ (homeopathic medicine) on the repair of bone lesions in male rats with osteoporosis induced by castration. Eighty-four three-month-old rats were used divided into four groups of twenty-one animals each. Three groups where castrated and one group was submitted to Sham surgery. One month later, cortical lesions were made in all animals' tibiae and, after one day, the different experimental treatments began according to the following groups: CR - castrated/Risedronate ( $1 \mathrm{mg} / \mathrm{kg} /$ day); CCp - castrated/Calcarea phosphorica $6 \mathrm{CH}$ (3 drops/day); CP - castrated/placebo and SP - Sham/placebo. The animals were sacrificed at seven, fourteen and twenty-eight days after the beginning of the treatments and had their tibiae removed. Digital radiographs of the tibiae were taken and analyzed in order to evaluate the optical density of the defect area. Then, they were decalcified and processed for histological and histomorphometrical analysis. The data were submitted to ANOVA, and to the Tukey and Dunnett tests (5\%). The allopathic and homeopathic treatments led to different bone formation as regards remodeling and maturation aspects. Further research is necessary to access the resistance and quality of the newly formed bone.
\end{abstract}

DESCRIPTORS: Allopathy; Homeopathy; Calcarea phosphorica; Fracture healing.

RESUMO: A osteoporose, doença caracterizada pela perda de massa óssea, tem sido alvo de estudos nos últimos anos. Fraturas decorrentes da osteoporose são muito comuns e podem apresentar consolidação mais lenta. O objetivo deste trabalho foi avaliar o efeito do risedronato (medicamento alopático) e da Calcarea phosphorica 6CH (medicamento homeopático) no reparo de lesões ósseas em ratos com osteoporose induzida por castração. Para tanto, foram utilizados oitenta e quatro ratos, com três meses de idade, separados em quatro grupos de vinte e um animais, sendo três grupos submetidos à castração e um grupo a falsa cirurgia ("Sham"). Um mês após a cirurgia, foram realizadas lesões corticais na tíbia de todos os animais e, a partir do dia seguinte, os tratamentos experimentais foram iniciados de acordo com os seguintes grupos: CR - castrado/risedronato (1 mg/kg/dia); CCp - castrado/Calcarea phosphorica $6 \mathrm{CH}$ (três gotas/dia); CP - castrado/placebo e SP - "sham"/placebo. Os animais foram sacrificados aos sete, catorze e vinte e oito dias após o início do tratamento e as tíbias foram removidas. Radiografias digitais foram realizadas e avaliadas para obter a densidade óptica na área do defeito. Em seguida, foram descalcificadas e processadas para análise histológica e histomorfométrica. Os dados foram submetidos a ANOVA e aos testes de Tukey e Dunnett (5\%). Os tratamentos alopático e homeopático levaram a formação óssea de aspecto diferente considerando a remodelação e maturação. Mais pesquisas são necessárias para avaliar a resistência e qualidade do osso neoformado.

DESCRITORES: Alopatia; Homeopatia; Calcarea phosphorica; Consolidação da fratura.

\section{INTRODUCTION}

Osteoporosis is a systemic disease, characterized by reduced bone mass and structural deterioration of bone tissue. It is considered a public health issue threatening a large portion of the population above 50 years of age $\mathrm{e}^{7,13,19}$. Often presenting as a silent disease, it generally occurs asymptomatically

\footnotetext{
* MScs, Graduate Program in Oral Biopathology; ${ }^{* *} \mathrm{PhD}$, Associate Professor; ${ }^{* * *} \mathrm{PhD}$, Professor - Department of Biosciences and Oral Diagnosis, School of Dentistry of São José dos Campos, São Paulo State University.
} 
Werkman C, Senra GS, Rocha RF, Brandão AAH. Comparative therapeutic use of Risedronate and Calcarea phosphorica-allopathy versus homeopathy - in bone repair in castrated rats. Braz Oral Res 2006;20(3):196-201.

and the afflicted individuals will be only diagnosed after the occurrence of some kind of fracture. One in two women and one in four men with age above fifty will have an osteoporosis related fracture in the course of their life ${ }^{7,13,19}$. The disease has a progressive course, with a tendency to entail fractures, and requires medical treatment ${ }^{1,3}$.

There are many options available to diagnose, treat and follow the progress of osteopenia and osteoporosis $^{6,7,12}$. There are image-based exams that allow density quantification of trabecular and cortical bone in a restricted area or in the entire body; each one with a precise indication ${ }^{1,3,4}$.

Health professionals have been searching for substances that can help increase the density of osteoporotic bones. That can be achieved either by diminishing bone resorption or improving bone formation. Bisphosphonates are being used widely in diseases that present increase in bone resorption, such as senile or post-menopause osteopenia/osteoporosis. Studies indicate that they stimulate a higher bone density increase than other drugs used with the same purpose, such as raloxifene or calcitonin. Among bisphosphonates, risedronate shows a higher anti-resorptive effect $\mathrm{t}^{2,3,8,14}$. Risedronate acts as an osteoclast inhibitor ${ }^{8,14}$. One hypothesis is that it prevents bone resorption by altering osteoclasts cytoskeleton's proteins or inhibiting cholesterol synthesis, which are necessary for the formation of the ruffled border, interfering directly with the fixation mechanisms of the osteoclasts to bone matrix ${ }^{3}$. The other hypothesis suggests that it induces the apoptosis of osteoclasts, by means of direct cytotoxic effects ${ }^{1}$.

In some bone diseases, alternative treatments other than the usual allopathic therapy have been used, including homeopathic treatments ${ }^{11}$.

Homeopathy proposes a new approach for comprehending and treating diseases, considering that a substance, once properly diluted and prepared, may induce symptoms that itself can alleviate. It defends cure by the similarity principle, presenting an antagonist ideology to conventional medicine which treats by the contrary law ${ }^{5,9,17}$. The goal of Homeopathy is to stimulate the body's own healing and defense mechanisms, leading its own cells to prevent and heal diseases ${ }^{5,18}$.

Calcarea phosphorica, formulated from calcium phosphate dilutions, is one of the homeopathic medicines prescribed for bone disease treatment ${ }^{17,18}$. Calcium phosphate, also known as hydroxyapatite, is the main structural component of bone matrix and comprehends around $85 \%$ of the body's phosphate ${ }^{9}$. Its homeopathic action heals several diseases related to the formation and remodeling of bone, therefore being prescribed for late bone callus formation, problems with fracture union, bone-deficient and abnormal growth, and for fractures followed by pain and paresis ${ }^{16,18}$. Its homeopathic cellular or functional mechanisms of action are still not documented, and even case reports based on clinical aspects are rare ${ }^{10}$.

Senra et al. ${ }^{15}$ (2004), while evaluating bone repair in hypertensive castrated rats treated with Risedronate, Calcarea phosphorica and Calcarea fluorica, observed that the animals treated with Calcarea phosphorica presented a higher optical density in the bone repair area than with the other treatments.

When a fracture or lesion occurs, the body mobilizes cells such as osteoclasts and osteoblasts to repair the injured bone. The osteoclasts absorb the necrotic bone and remodel the new bone created by osteoblasts that proliferate intensively and produce the new matrix. These cells work simultaneously forming an immature bone callus, which shows progressive remodeling until complete replacement by mature bone ${ }^{7}$.

In osteoporotic bones, the osseous turnover does not occur in an adequate way because in the remodeling process bone formation is diminished and resorption is increased ${ }^{19}$.

In spite of the vast research existing on the evolution and treatment of osteoporosis there are few studies evaluating the process of bone repair in osteoporotic individuals. The full impact of osteoporosis on the consolidation of bone fractures is still not completely understood, and it is possible that the drugs used for its treatment may interfere with the repair process. Thus, studies on alternative treatments for osteoporosis are necessary, valid, can contribute to a better understanding of the disease and may improve the quality of life of osteoporotic individuals. There are many alternative treatment options that could offer equivalent results, with less complications and side effects, which deserve to be explored in more depth.

The aim of this work was to study and compare the effects of the allopathic medication Sodium Risedronate and the homeopathic medicine Calcarea phosphorica $6 \mathrm{CH}$ on the bone repair of male castrated rats through histomorphological, histomorphometrical and bone optical density analyses. 
Werkman C, Senra GS, Rocha RF, Brandão AAH. Comparative therapeutic use of Risedronate and Calcarea phosphorica- allopathy versus homeopathy - in bone repair in castrated rats. Braz Oral Res 2006;20(3):196-201.

\section{MATERIAL AND METHODS}

Sixty-three male rats, three months old, underwent castration, by testicle removal via scrotal bag, for osteoporosis induction, and twenty-one rats were submitted to Sham surgery. They were submitted to anesthesia using IM $2 \%$ xylazine hydrochloride (Rompun, Bayer, São Paulo, SP, Brazil) and ketamine (Dopalen, Agribrands do Brasil, Divisão Vetbrands Saúde Animal, Jacareí, SP, Brazil) $(1: 0.5 \mathrm{ml})$. One month later, all animals were operated to create a $3 \mathrm{~mm}$ cortical lesion on the medial face of the tibiae's proximal extremity, using a $2.5 \mathrm{~mm}$ trephine followed by a $\mathrm{n} .8$ carbide spherical burr. From the following day on, using mechanical restraint, the medication or placebo drops were orally given, according to the groups: Sham/placebo (3 drops/day of distilled water) (SP), castrated/placebo (3 drops/day of distilled water) (CP), castrated/Calcarea phosphorica 6CH (Pharmaciantiga, São José dos Campos, SP, Brazil) (3 drops/day) (CCp) and castrated/Sodium Risedronate (Hoechst, Suzano, SP, Brazil) $(1 \mathrm{mg} / \mathrm{kg}$ in 3 drops/day) (CR).

On the $7^{\text {th }}, 14^{\text {th }}$, and $28^{\text {th }}$ day of treatment, the animals were sacrificed with anesthesia overdose and had their tibiae removed and radiographed using a CCD sensor from the direct digital system RVGui, version 5.0 (Trophy Radiology, MarnelaVallée, France) connected to the $65 \mathrm{kVp}$ X-ray Gendex 765DC (Gendex Dental Systems, Dentsply International, Chicago, IL, USA). The images where analyzed by Image Tool (UTHSCSA Image Tool version 3.0) to assess the optical density and localization of the wounded area.

The material was then decalcified using Plank solution for a period of six months and submitted to histological processing. Semi-seriated, five-micron thick sections were stained with hematoxylin and eosin and submitted to morphological analysis. Histomorphometrical analysis to assess the percentage of bone formed on the lesional area was done using Image $\mathrm{J}$ software (http://rsb.info.nih. gov/ij) by overlaying a 72 points (300 by 150 pixel) grid onto the central area of the wound, which was the last area to repair in the lesion.

All data were submitted to ANOVA, and to Tukey and Dunnett tests (5\%).

\section{RESULTS}

Through histomorphological and histomorphometric analyses it was possible to observe that by the $7^{\text {th }}$ day all groups showed a great bone callus constituted by trabecular bone, filling the defect and extending into the medullary space; the CCp group showed a smaller callus than the other groups. By the $14^{\text {th }}$ day the callus resorption was intense in the SP group and mild in the CCp and CR groups. By the $28^{\text {th }}$ day of the repair process the bone was more mature and changing to a lamellar aspect. The CR group had the thickest callus with a great amount of bone of trabecular aspect filling the defect and still extending into the medullary space (Figure 1). The CCp group displayed a thin lamellar compact bone without trabecular aspect, with some areas tightly connected to the adjacent cortical (Figure 2). The CP and SP groups showed a thin sheet of trabecular bone with areas of lamellar aspect (Figures 3 and 4).

A variable quantity of fibrous connective tissue over the wound area was observed in the four groups (Figures 1, 2, 3 and 4).

The histomorphometrical analysis results can be observed in Graph 1 demonstrating the quantity of bone formed and the remodeling during the experiment in all four groups.

The optical density evaluation showed a progressive growing density in the Risedronate group. The Calcarea phosphorica group showed the higher density until the $14^{\text {th }}$ day, falling by the $28^{\text {th }}$ day. The SP group displayed a decreasing density from day 7 to day 28 and the CP group displayed a stable density throughout the experiment (Graph 2).

\section{DISCUSSION}

The greater bone quantity in the CR group evidences Risedronate's pharmacological effects, leading to the prevention of bone resorption also in the bone formed in the callus. The amount and morphologic aspect of bone observed in the CCp group indicates that bone formation occurred, but its resorption was not prevented by the Calcarea phosphorica treatment. Although Risedronate led to a greater quantity of bone formation, it maintained a trabecular aspect until the $28^{\text {th }}$ day, while Calcarea phosphorica presented a remodeling that led to a more compact, lamellar, mature bone, similar to that of a normal cortical (Figures 1 and 2).

The small quantity of bone and the poor remodeling observed in the $\mathrm{CP}$ group was probably due to a response to castration allied to the placebo 
Werkman C, Senra GS, Rocha RF, Brandão AAH. Comparative therapeutic use of Risedronate and Calcarea phosphorica-allopathy versus homeopathy - in bone repair in castrated rats. Braz Oral Res 2006;20(3):196-201.

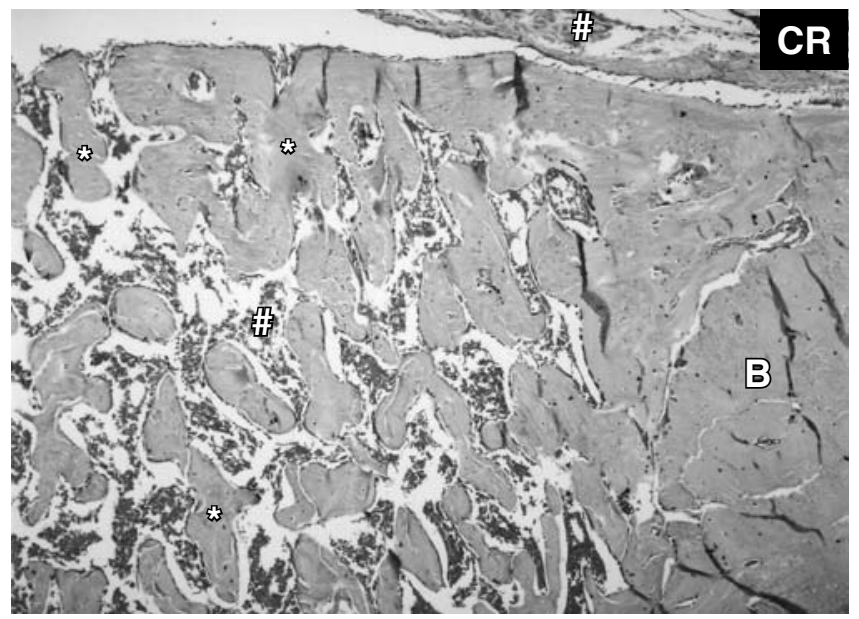

FIGURE 1 - Morphologic aspects observed in the CR (castrated/Sodium risedronate) group at 28 days of treatment. Lesion closed by a large amount of trabecular bone without remodeling to lamellar aspect. H. E. $400 \mathrm{X}$. * = newly formed bone; $\mathrm{B}$ = adjacent cortical; \# = connective tissue.

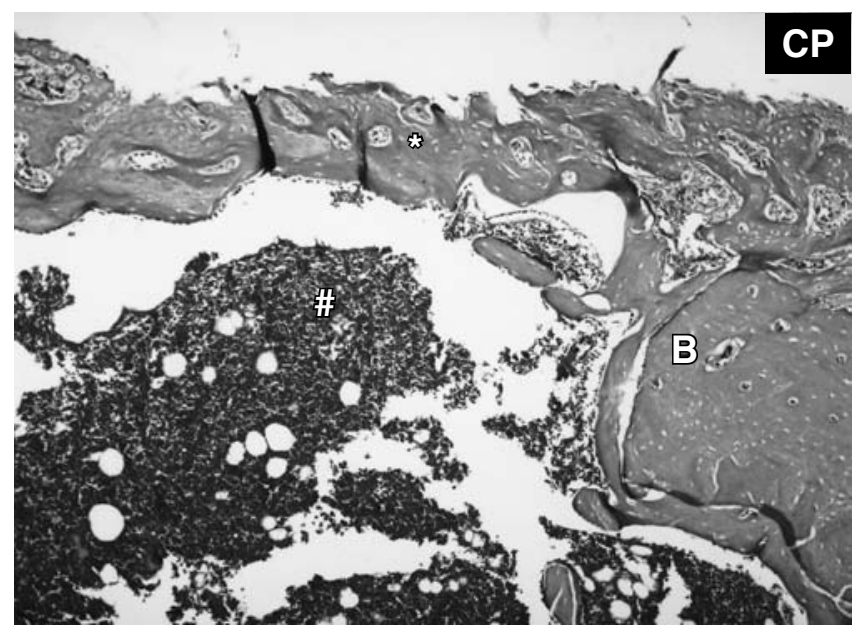

FIGURE 3 - Morphologic aspects observed in the CP (castrated/placebo) group at 28 days of treatment. Lesion closed by a thin sheet of trabecular bone with poor remodeling to lamellar aspect. H. E. $400 \mathrm{X} .{ }^{*}=$ newly formed bone; $\mathrm{B}=$ adjacent cortical; $\#$ = connective tissue.

treatment, leading to a low bone formation and high resorption (Figure 3).

In the SP group, considered the normal control, the remodeling and maturation process was not complete, resulting in trabecular and lamellar bone formation (Figure 4).

Comparing the radiographic data with the histomorphological and histomorphometrical analyses, it became clear that not only the quantity but also the quality and density of bone interfere with the values as well as the fibrous tissue interposed

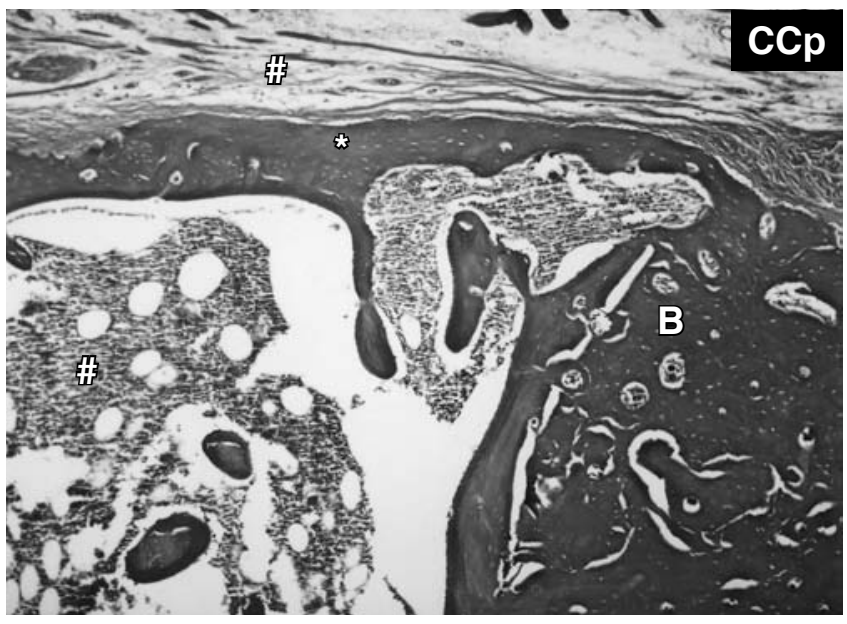

FIGURE 2 - Morphologic aspects observed in the CCp (castrated/Calcarea phosphorica $6 \mathrm{CH}$ ) group at 28 days of treatment. Lesion closed by thin lamellar compact bone without trabecular aspect. H. E. $400 \mathrm{X}$. * = newly formed bone; $\mathrm{B}=$ adjacent cortical; $\#=$ connective tissue.

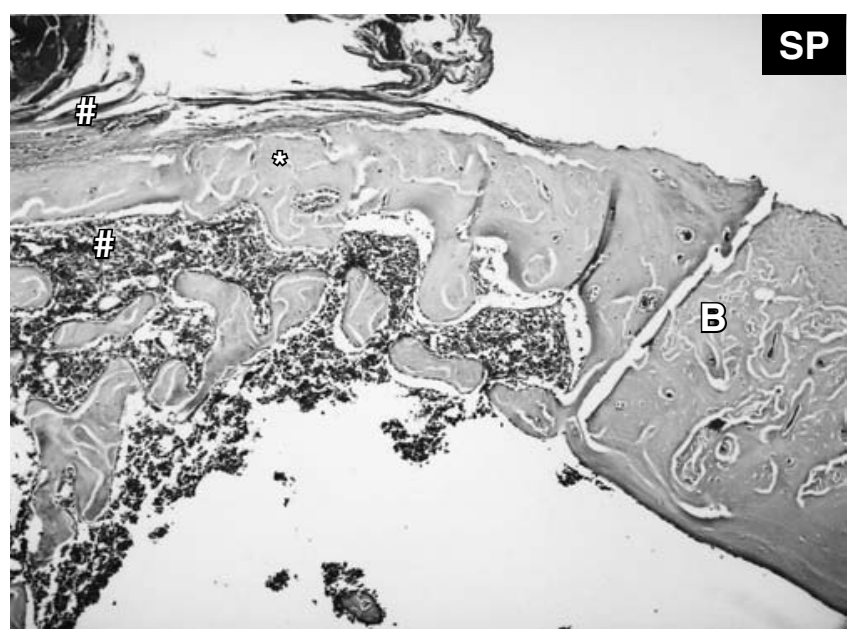

FIGURE 4 - Morphologic aspects observed in the SP (Sham/placebo) group at 28 days of treatment. Lesion closed by trabecular and lamellar bone. H. E. $400 \mathrm{X}$. * = newly formed bone; $\mathrm{B}=$ adjacent cortical; \# = connective tissue.

in the radiographic images, contributing to the optical density variations observed.

\section{CONCLUSION}

The Risedronate treatment influenced repair, leading to a greater bone quantity than that induced with Calcarea phosphorica $6 \mathrm{CH}$. However, the bone formed under the Risedronate treatment displayed a resistance to resorption, keeping its trabecular aspect, while the Calcarea 
Werkman C, Senra GS, Rocha RF, Brandão AAH. Comparative therapeutic use of Risedronate and Calcarea phosphorica- allopathy versus homeopathy - in bone repair in castrated rats. Braz Oral Res 2006;20(3):196-201.

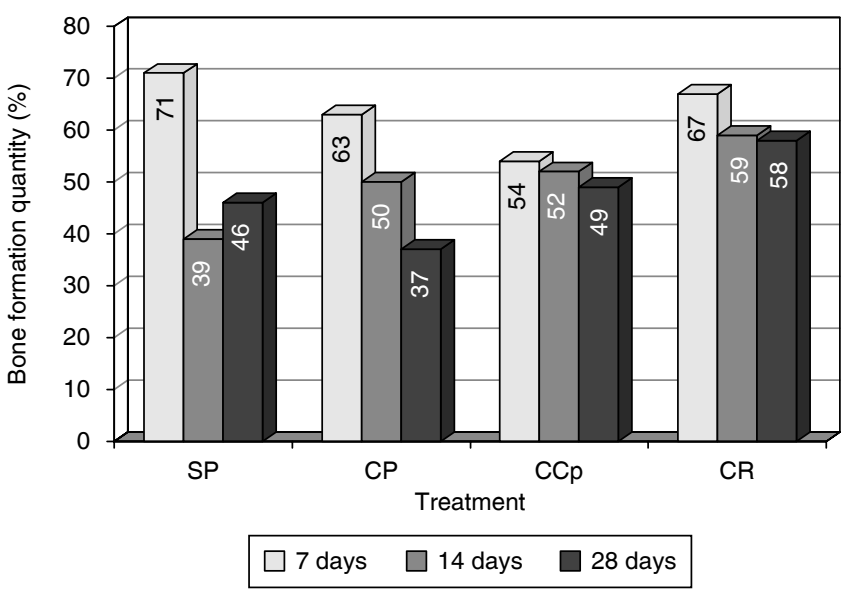

GRAPH 1 - Histomorphometrical results: graph demonstrating the quantity of bone formed in the wound area submitted to different treatments, at 7, 14 and 28 days. $\mathrm{SP}=\mathrm{Sham} /$ placebo; $\mathrm{CP}=$ castrated $/$ placebo; $\mathrm{CCp}=$ castrated $/$ Calcarea phosphorica $6 \mathrm{CH}$; CR = castrated/Risedronate.

phosphorica $6 \mathrm{CH}$ bone changed from an initially trabecular to a lamellar bone at the end of the experiment.

The allopathic and homeopathic treatments led to different bone formation results regarding remodeling and maturation aspects. Further research is therefore necessary to assess the resistance and quality of the formed bone.

Repair evaluation through optical density analysis does not faithfully describe the bone cal-

\section{REFERENCES}

1. Bae DC, Stein BS. The diagnosis and treatment of osteoporosis in men on androgen deprivation therapy for advanced carcinoma of the prostate. J Urol 2004;172(6 Pt 1):2137-44.

2. Blake GM, Fogelman I. Bone densitometry, steroids and osteoporosis. Curr Opin Nephrol Hypertens 2002;11(6):641-7.

3. Boonen S, Haentjens P, Vandenput L, Vanderschueren D. Preventing osteoporotic fractures with antiresorptive therapy: implications of microarchitectural changes. J Intern Med 2004;255(1):1-12.

4. Calero JA, Curiel MD, Moro MJ, Carrascal MT, Santana JS, Avial MR. Speed of sound, bone mineral density and bone strength in oophorectomized rats. Eur $\mathrm{J}$ Clin Invest 2000;30(3):210-4.

5. Fisher P, Scott DL. A randomized controlled trial of homeopathy in rheumatoid arthritis. Rheumatology (Oxford) 2001;40(9):1052-5.

6. Fogelman I, Ribot C, Smith R, Ethgen D, Sod E, Reginster JY. Risedronate reverses bone loss in postmenopausal women with low bone mass: results from a multinational, double-blind, placebo-controlled trial. J Clin Endocrinol Metab 2000;85(5):1895-900.

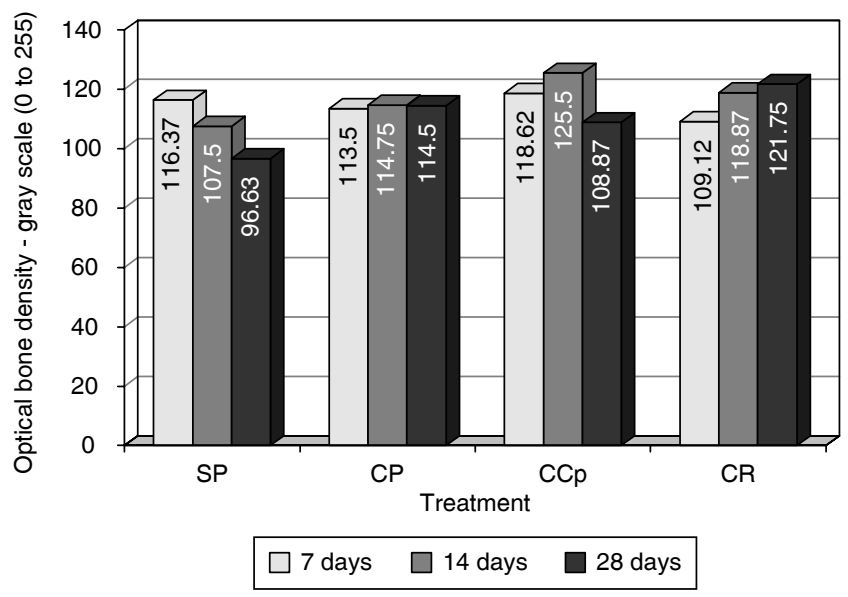

GRAPH 2 - Optical bone density results: graph demonstrating the optical density of the wound area submitted to different treatments, at 7, 14 and 28 days. $\quad \mathrm{SP}=$ Sham $/$ placebo; $\quad \mathrm{CP}=$ castrated $/$ placebo; $\mathrm{CCp}=$ castrated $/$ Calcarea phosphorica $6 \mathrm{CH}$; CR = castrated/Risedronate.

lus' morphological course because it does not consider the differences between the trabecular and lamellar bones and also because it adds the fibrous connective tissue to the measurements.

\section{ACKNOWLEDGEMENT}

We wish to thank the Coordination for the Improvement of Higher Education Personnel (CAPES) for financial support.

7. Guedes Junior FS. Osteoporose [Monografia de Especialização]. Vitória: Escola de Medicina da Santa Casa de Misericórdia de Vitória; 2003.

8. Harris ST, Watts NB, Genant HK, McKeever CD, Hangartner T, Keller M, et al. Effects of Risedronate treatment on vertebral and nonvertebral fractures in women with postmenopausal osteoporosis: a randomized controlled trial. Vertebral Efficacy With Risedronate Therapy (VERT) Study Group. JAMA 1999;282(14):1344-52.

9. Higdon J. Phosphorus. Oregon State University. Linus Pauling Institute. 2003. [cited 2004 Nov 17]. Available from: $h t t p: / / l p i$. oregonstate.edu/infocenter/minerals/phosphorus.

10. Jobst KA. Homeopathy, Hahnemann, and The Lancet 250 Years On: a case of the Emperor's New Clothes? J Altern Complement Med 2005;11(5):751-4.

11. Jones JE, Kassity N. Varieties of alternative experience: complementary care in the neonatal intensive care unit. Clin Obstet Gynecol 2001;44(4):750-68.

12. Leder BZ, LeBlanc KM, Schoenfeld DA, Eastell R, Finkelstein JS. Differential effects of androgens and estrogens on bone turnover in normal men. J Clin Endocrinol Metab 2003;88(1):204-10. 
Werkman C, Senra GS, Rocha RF, Brandão AAH. Comparative therapeutic use of Risedronate and Calcarea phosphorica-allopathy versus homeopathy - in bone repair in castrated rats. Braz Oral Res 2006;20(3):196-201.

13. National Osteoporosis Foundation [homepage on the Internet] [Cited 2004 Jun 20]. Available from: http://www. nof.org/osteoporosis.

14. Reginster J, Minne HW, Sorensen OH, Hooper M, Roux C, Brandi ML, et al. Randomized trial of the effects of risedronate on vertebral fractures in women with established postmenopausal osteoporosis. Vertebral Efficacy with Risedronate Therapy (VERT) Study Group. Osteoporos Int 2000;11(1):83-91.

15. Senra GS, Werkman C, Rocha RF, Brandão AAH. Estudo radiográfico do reparo ósseo em ratos SHR com osteoporose utilizando homeopatia e risedronato. In: Programas e Resumos da $5^{\text {a }}$ Mostra de pós-graduação da Universidade de Taubaté; 2004. Taubaté: Universidade de Taubaté; 2004. p. 306. outubro; Taubaté.

16. Tyler ML. Calcarea phosphorica. In: Tyler ML. Retratos de medicamentos homeopáticos. São Paulo: Santos; 1992. cap. 1. p. 181-7.

17. Ullman D. Homeopathic medicine: principles and research. In: Shoen AM, Wynn SG. Complementary and alternative veterinary medicine. Crawfordsville: R. R. Donnelley; 1998. p. 469-84.

18. Voisin H. Manual de matéria médica para o clínico homeopata. $2^{a}$ ed. São Paulo: Andrei; 1987.

19. Watts NB. Diagnosis and evaluation of patients with osteoporosis. South Med J 2004;97(6):540-1.

Received for publication on Jan 30, 2006

Sent for alterations on Apr 05, 2006

Accepted for publication on May 25, 2006 